\title{
28. X-RAY MINERALOGY STUDIES, LEG 48-ROCKALL REGION (SITES 403, 404, 405, AND 406)
}

\author{
C. Latouche and N. Maillet, Institut de Géologie du Bassin d'Aquitaine \\ (Laboratoire associé au C.N.R.S. No. 197), Université de Bordeaux I, France
}

\section{METHODS}

X-ray diffraction was used on a total of 190 samples in the mineralogical analysis of the fine-grained fraction (calcium carbonate-free fraction $<2 \mu \mathrm{m}$ ) using smear slides and three-diagram X-ray method, and in analysis of bulk samples using powders and an internal standard.

\section{Clay Fraction $(<2 \mu \mathrm{m})$}

Total sediments were dispersed in pure water by mechanical agitation. Samples with a high content of carbonates were first treated with $\mathrm{HCl} \mathrm{N} / 10$. After two or three washings in pure water, $<2 \mu \mathrm{m}$ subfractions were separated by settling. The $<2 \mu \mathrm{m}$ portion of suspensions was centrifugalized and the thick paste obtained then was spread across two slides with a standard laboratory spatula. The amount of clay per $\mathrm{cm}^{2}$ was conditioned by the amount transferred to the slide. The first slide was saturated with ethylene glycol before analysis. The second slide was scanned untreated and then heated at $550^{\circ} \mathrm{C}$ for one hour before secondary analysis.

The diffractometer used is a C.G.R. theta 60 and operating conditions were as follows: $\mathrm{Cu} \mathrm{K} \alpha$ radiation (very fine focus $0.1 \times 5 \mathrm{~mm}$ ) equipped with a Guinier monochromator; 40 $\mathrm{kv}, 10 \mathrm{~mA}$, scanning speed $0.5^{\circ} \theta \mathrm{p}$ min.

Minerals were identified on the basis of their typical reactions to classical treatment (Brown, 1961; Thorez, 1975). Several diagrams exhibited high background between 5.6 and $3.6 \AA$. This particularity is attributed to amorphous silica (Trichet, 1970; Greenwood, 1973).

The different minerals were estimated semiquantitatively from diagrams of the glycolated slides. The height of 001 peaks was used to determine the percentage of smectite $(17 \AA)$, illite $(10 \AA)$, and kaolinite + chlorite $(7.1 \AA)$, chlorite being distinguished from kaolinite on the basis of the difference in their reflections, i.e., 002 for kaolinite and 004 for chlorite. Several non-clay minerals (zeolite, silica, etc.) are associated with the $<2 \mu \mathrm{m}$ fraction. The abundance of zeolite of the clinoptilolite type ( $9 \AA$ line which persists on heating; Mumpton, 1960), was estimated as with that of the clay minerals, on the basis of the height of their characteristic reflections. Siliceous minerals of the opal-CT type gave a doublet of lines at 4.45 and $4.25 \AA$. The presence of amorphous silica was noted consistently, from scattering background.

\section{Total Sediments}

Dried and pulverized samples of total sediments were analyzed according to the powder diagrams method using an internal standard (corindon). By a comparison with synthetic reference samples, this method enabled us to obtain semiquantitative estimates of quartz ( $3.35 \AA$ ) and feldspars (al- kaline, $3.25 \AA$; plagioclase, $3.20 \AA$ ). The diffractometer used is a Philips 1310 and operating conditions were as follows: nickel-filtered copper $\mathrm{K} \alpha$ radiation at $40 \mathrm{kv}, 20 \mathrm{~mA}$; automatic sample changer; step-scanning device and monitoring system of the goniometer. The proportion of carbonates was calculated by calcimetry.

\section{GENERAL OUTLINE OF THE MINERALOGY OF DEPOSITS}

Fractions with a granulometry of less than $2 \mu \mathrm{m}$ are composed of both clay minerals and various non-clay constituents. Their possible origins and their significance were considered in the light of works by several authors, in particular, that of Mason et al. (1960), Millot (1964), YeroschevShak (1964), Biscaye (1965), Bonatti (1967), Griffin et al. (1968), Rateev et al. (1969), Paquet (1969), Tardy (1969), Trichet (1970), Chamley (1971), Latouche (1971), and Jones et al. (1971).

\section{Clay Minerals}

Clay minerals are mainly represented by smectites, illites, chlorites, and kaolinites, in order of importance.

Smectites are predominant from the Eocene to the upper Miocene. They are poorly crystallized in the lower Eocene at Sites 403 and 404 (wide peaks with very rounded summits). These smectites are slow to swell when treated with ethylene glycol, as previously noted by Fan and Zemmels (1972) with samples from Leg 12 . They are very well crystallized in the same period at Sites 405 and 406 .

These minerals may be detrital resulting from the erosion of neighboring continental soils subjected to a climate of contrasting seasons; or they may come from the alteration and evolution of basic volcanic material; or again, they may be due to neoformations in a more or less confined basin rich in silica.

Illites are particularly abundant in the Miocene and Pliocene/Pleistocene and are generally accompanied by chlorites. These clay species are common at the present time in marine deposits and more especially periglacial regions. Their presence, therefore, may indicate pelagodetritic sediments of northern origin.

Kaolinites are poorly represented and occur especially in the Pleistocene. It is generally admitted that their origin is detrital and continental.

\section{Non-Clay Minerals}

Zeolites of clinoptilolite type are abundant in the Eocene at Sites 403 and 404 (where the clay phases are exclusively smectitic). Suggestions vary as to their origin and mode of formation. According to Nayudu (1964), in continuation of 
the work of Goldberg (1959), their association with smectites could indicate a derivation from the alteration of basic volcanic rocks; this appears to be the case at these two sites.

Silica (crystalline, in the form of opal-CT, or else amorphous) appears in the Eocene at Site 405 and from the Eocene to the lower Miocene at Site 406. The formation of opal-CT implies an environment rich in silica. Leclaire (1974) suggests three sources of silica in sea-water: (1) derived from alteration of the continents; (2) derived from alteration of the basaltic ocean floor; (3) recycling by redissolution of silica precipitated by plankton. In their study of sediments in the Law-Basin, Griffin et al. (1972) associate the presence of cristobalite-tridymite with eruptions of lava rich in silica. In this case, however, it should be noted that the cristobalitetridymite is attended by numerous fragments of volcanic rocks. The amorphous silica appears to be largely biogenic, as suggested by the frequency of siliceous organisms in the episodes where amorphous silica has been observed.

\section{Bulk Samples}

The principal mineral components are carbonates and quartz-feldspars. Carbonates, here represented by calcite, are very abundant in the Miocene and the Oligocene. They have been regarded as mainly biogenic, without excluding the possibility of disturbance of older carbonates. Quartz and feldspars occur in limited quantities but in well-defined episodes in the lower Eocene at Sites 403 and 404 and from the Pliocene on at all four sites. They have been considered as detritus of continental origin.

\section{RESULTS}

On the basis of mineralogical characteristics, two groups were isolated: Sites 403 and 404 and Sites 405 and 406; several successive mineralogical assemblages were distinguished along the line of bore holes. These assemblages are defined in terms of the stratigraphic units proposed in the shipboard report and of the lithological units.

\section{Sites 403 and 404 (Figures 1 and 2, Tables 1 and 2)}

Three types of mineralogical associations appear at these sites. Assemblage 1 at Site 403 corresponds to Units $3 \mathrm{~A}$ and 3B (Paleocene, lower Eocene), Sections 403-43-1, to 40328-1 inclusive; and at Site 404, to Units 3A, 3B, and 2 (Paleocene, lower and middle Eocene, and middle Miocene), Sections 404-26-1 to 404-7-2, inclusive.

The dominant characteristics of this mineralogical assemblage are: smectites, very abundant and poorly crystallized (e.g., peak wide and rounded at Site 403 ) to very poorly crystallized (Site 404); zeolites (clinoptilolite), frequently present and often plentiful; quartz and feldspars (plagioclases predominate); carbonates, relatively scarce; and amorphous silica, frequently present (especially at Site 403).

The sedimentation is probably detrital. The smectites appear to come from soils characteristic of climates with contrasting seasons and in all likelihood from the products of weathering of basic volcanic rocks. This type of climate has often been described as being Eocene. Nevertheless, associations of poorly crystallized smectites with plagioclase feldspars, zeolites, and amorphous silica have already been recorded (Latouche, 1975) in present-day marine deposits in the neighborhood of the basaltic Faeroes archipelago in a cool, temperate climate. This seems to show that the parent rock is the most important factor.

Assemblage 2 at Site 403 corresponds to Units 2 and 1B (middle Eocene, lower middle Oligocene, upper Miocene, and base of upper Pliocene), Sections 403-26-2 to 403-7-1, inclusive; and at Site 404, to Unit 1B (upper Miocene and lower Pliocene), Sections 404-5-2 to 404-3-1, inclusive.

The dominant mineralogical characteristics are: smectites, abundant or relatively abundant and highly crystalline; illites, always present; appearance of chlorite and kaolinite; and high proportion of carbonates (about $80 \%$ ). Quartz and feldspars are absent.

The sedimentation is of pelagic type (rich in biogenic carbonates but without detritus of quartz and feldspars) and includes fine-grained elements with abundant smectites, characteristic of pedogenesis under a hot climate. Nonetheless, the abrupt appearance of illite and chlorite suggests alimentation from sources in northern latitudes. This might be a sign of the establishment of deep-ocean circulation in this region.

Assemblage 3 at Site 403 corresponds to Unit 1A (end of upper Pliocene and Pleistocene), Sections 403-5-2 to 403-14, inclusive; and at Site 404, to Unit 1A (upper Pliocene and Pleistocene), Sections 404-2-6 to 404-1-1.

The dominant characteristics are: illites, very abundant (dominant in Site 403); smectites, present; chlorites and kaolinites, better represented than in Assemblage 2; carbonates, in varying quantities but less abundant than in Assemblage 2; and the reappearance of quartz and feldspars.

The increase in illite and chlorite indicates increased alimentation from northern sources and/or a local cooling of the climate. The reappearance of quartz and feldspars suggests a coarser-grained sedimentation. This would mean that ocean currents had a greater competence and implies a reinforcement of circulation in the ocean. The colder climate may also entail sedimentation of elements brought by icerafting.

\section{Sites 405 and 406 (Figures 3 and 4, Tables 3 and 4)}

Again, there are three mineralogical assemblages. The first in this series is distinctly different from the first assemblage described for Sites 403 and 404; for this reason it is designated 1B. Conversely, the two other assemblages are identical to those at Sites 403 and 404 .

Assemblage 1B at Site 405 corresponds to Units 2D, 2C, $2 \mathrm{~B}$, and $2 \mathrm{~A}$ (lower and lower-middle Eocene), Sections 405-43-6 to 405-8-2, inclusive; and at Site 406, to Units 5, 4C, 4B, 4A, and 3 (upper Eocene, upper-middle and upper Oligocene, and lower Miocene), Sections 406-49-1 to 40626-2, inclusive.

The dominant characteristics are the exclusive presence of very highly crystalline smectites where clay minerals are represented, alternate presence of opal CT (sometimes the only component in the fraction of $<2 \mu \mathrm{m}$ ) and amorphous silica, carbonates in varying quantities (low in Site 405, high in Site 406), and very exceptionally quartz and feldspars.

The high content of crystalline or amorphous silica, coupled with the scarcity of quartz, suggests a "chemical" type sedimentation. The origin of silica remains to be explained as the result of intensive leaching under a hot, damp climate, or possibly a hydrothermal origin. The alter- 


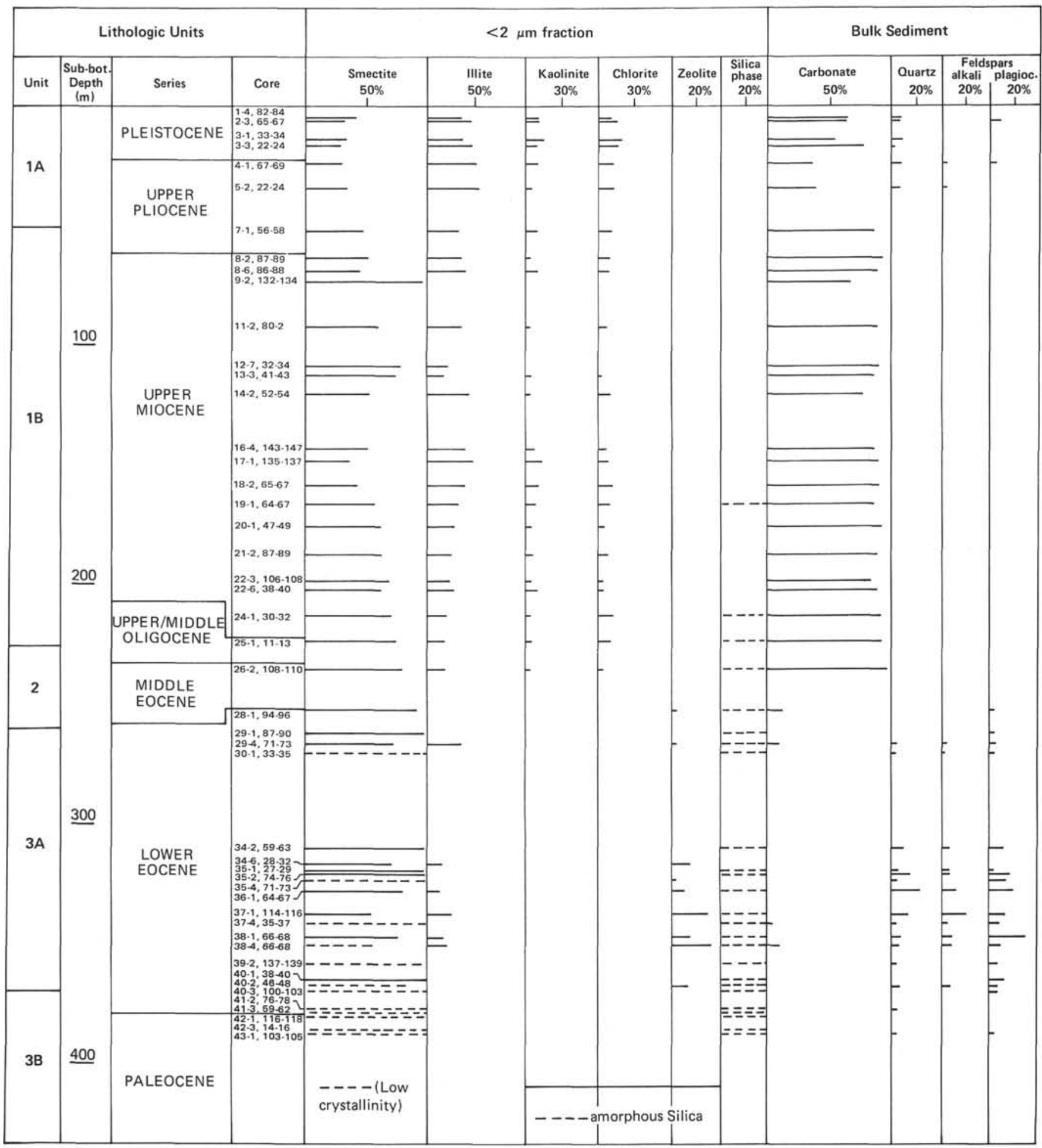

Figure 1. Mineralogical log of Site 403.

nation of crystalline and amorphous forms might be explained by the concentration of silica in the waters: high concentration due to precipitation of opal by saturation, and lesser concentration caused by the development of siliceous organisms whose tests enrich the deposit in amorphous silica.

Assemblage 2 corresponds to part of Unit 1B at Site 405 (upper Miocene), Sample 405-7-1, 11-13 cm; and to Units
2B and a part of 2A at Site 406 (middle and upper Miocene and base of lower Pliocene), Samples 406-24-2 to 406-4-2, 96-98 cm inclusive.

The dominant characteristics are a sudden appearance of illites, chlorites, and kaolinites, and an abundance of smectites. Carbonates are very abundant, while quartz and feldspars are absent. 


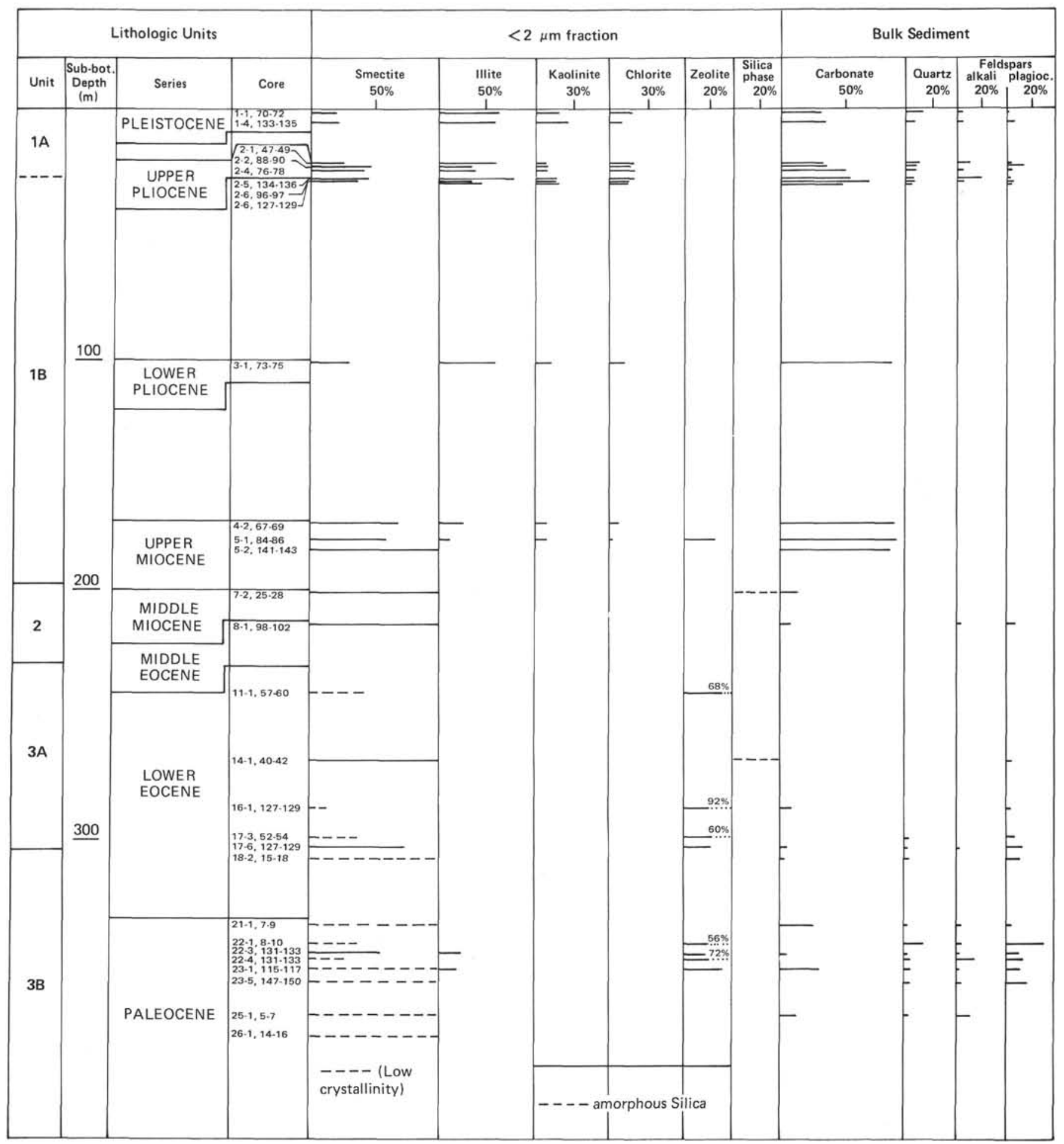

Figure 2. Mineralogical log of Site 404.

This episode is extremely condensed in Site 405 and marks a sharp transformation in relation to the underlying units. This assemblage is identical with Assemblage 2 at Sites 403 and 404 and holds the same significance, i.e., carbonated pelagic deposits associated with very fine, clayish, detrital material in which the abundance of smectites is evidence of pedogenesis under a hot climate. Besides this, the abrupt appearance of illites and chlorites suggests a second type of alimentation from colder zones and, therefore, the estab- lishment of deep-water circulation originating in northern latitudes.

Assemblage 3 at Site 405 corresponds to Units 1B (in part) and 1A (lower Pliocene to Pleistocene), Sections 405-6-1 to 405-1-1, inclusive; and at Site 406, to Units $2 \mathrm{~A}$ (in part) and 1 (lower Pliocene to Pleistocene), Sections 406-4-1, 116-118 $\mathrm{cm}$, to 406-1-1, inclusive.

The dominant characteristics are predominance of illites; chlorites and kaolinites, well represented; smectites, present; 
TABLE 1

X-Ray Diffraction Analyses of the Fine-Grained $(<2 \mu \mathrm{m})$ and Bulk Samples From Site 403

\begin{tabular}{|c|c|c|c|c|c|c|c|c|c|c|c|c|c|}
\hline \multirow[b]{2}{*}{$\begin{array}{c}\text { Sample } \\
\text { (Interval in cm) }\end{array}$} & \multirow[b]{2}{*}{$\begin{array}{l}\text { Depth } \\
\text { (m) }\end{array}$} & \multicolumn{7}{|c|}{$<2 \mu$ m Fraction } & \multicolumn{5}{|c|}{ Bulk Sediment } \\
\hline & & 莺 & 弟 & 莺 & 을 & 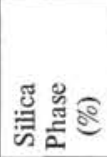 & 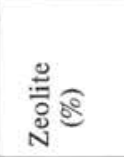 & Comment & 苞 & 总 & 을 & 冚 & $\begin{array}{l}\stackrel{0}{0} \\
\frac{\pi}{0} \\
\stackrel{0}{0} 8 \\
\frac{\pi}{2}\end{array}$ \\
\hline $1-4,82-84$ & 5.32 & 43 & 32 & 13 & 12 & - & - & & 6 & 63 & - & - & - \\
\hline $2-3,65-67$ & 6.65 & 32 & 39 & 11 & 18 & - & - & & 3 & 61 & - & - & 8 \\
\hline $3-1,33-34$ & 14.33 & 35 & 30 & 15 & 20 & - & trace & & 5 & 53 & - & - & - \\
\hline $3-3,22-24$ & 17.22 & 31 & 39 & 12 & 18 & - & trace & & 1 & 76 & - & - & - \\
\hline $4-1,67-69$ & 24.17 & 32 & 42 & 12 & 14 & - & trace & & 6 & 35 & - & 1 & 3 \\
\hline $5-2,22-24$ & 34.77 & 36 & 42 & 8 & 14 & - & trace & & 7 & 38 & - & 1 & 1 \\
\hline $7-1,56-58$ & 52.56 & 49 & 27 & 11 & 13 & - & - & & trace & 86 & - & - & - \\
\hline $8-2,87-89$ & 63.87 & 54 & 30 & 5 & 11 & - & - & & - & 92 & - & - & - \\
\hline $8-6,86-88$ & 69.86 & 46 & 33 & 11 & 10 & - & - & & - & 90 & - & - & - \\
\hline $9-2,132-134$ & 73.82 & 100 & - & - & - & - & - & & trace & 76 & - & - & - \\
\hline $11-2,80-82$ & 92.30 & 60 & 28 & 5 & 7 & - & trace & & - & 88 & - & - & - \\
\hline $12-7,32-34$ & 108.82 & 80 & 20 & trace & trace & - & - & & - & 88 & - & - & - \\
\hline $13-3,41-43$ & 112.41 & 77 & 14 & 5 & 4 & - & - & & - & 86 & - & - & - \\
\hline $14-2,52-54$ & 120.52 & 50 & 35 & 4 & 11 & - & - & & - & 84 & - & - & - \\
\hline $16-4,143-147$ & 143.43 & 54 & 31 & 9 & 6 & - & presence & & - & 84 & - & - & - \\
\hline $17-1,135-137$ & 148.35 & 37 & 40 & 14 & 9 & - & - & & - & 90 & - & - & - \\
\hline $18-2,65-67$ & 158.65 & 43 & 33 & 12 & 12 & - & - & & - & 90 & - & - & - \\
\hline $19-1,64-67$ & 166.64 & 57 & 27 & 7 & 9 & - & - & & - & 86 & - & - & - \\
\hline $20-1,47-49$ & 175.97 & 64 & 23 & 7 & 6 & - & - & & trace & 91 & - & - & - \\
\hline $21-2,87-89$ & 187.37 & 64 & 22 & 6 & 8 & - & - & & - & 86 & - & - & - \\
\hline $22-3,106-108$ & 198.56 & 70 & 20 & 6 & 4 & - & - & & - & 84 & - & - & - \\
\hline $22-6,38-40$ & 202.38 & 62 & 23 & 10 & 5 & - & - & & trace & 88 & - & - & - \\
\hline $24-1,30-32$ & 213.80 & 71 & 16 & 3 & 10 & - & - & & - & 90 & - & - & - \\
\hline $25-1,11-13$ & 223.11 & 74 & 14 & 3 & 9 & - & presence & & - & 92 & - & - & - \\
\hline $26-2,108-110$ & 235.08 & 79 & 14 & 4 & 3 & - & presence & & trace & 95 & - & - & - \\
\hline $28-1,94-96$ & 252.44 & 94 & - & - & - & - & 6 & & - & 10 & - & - & 7 \\
\hline $29-1,87-90$ & 261.87 & 100 & - & - & - & - & - & & - & - & - & - & 3 \\
\hline $29-4,71-73$ & 266.21 & 73 & 27 & - & - & - & trace & & 3 & 10 & - & 3 & 5 \\
\hline $30-1,33-35$ & 270.83 & 100 & - & - & - & - & - & not much clay & 3 & - & - & 2 & 2 \\
\hline $34-2,59-63$ & 310.59 & 100 & - & - & - & - & trace & & 11 & - & - & 5 & 12 \\
\hline $34-6,28-32$ & 316.28 & 71 & 15 & - & _- & _- & 14 & & - & - & - & - & - \\
\hline $35-1,27-29$ & 318.27 & 100 & - & - & - & - & presence & & 4 & - & - & 5 & $>50$ \\
\hline $35-2,74-76$ & 320.24 & 100 & - & - & - & - & - & & 14 & - & - & 5 & 18 \\
\hline $35-4,71-73$ & 323.21 & 100 & - & - & _- & - & trace & & 3 & - & - & trace & 11 \\
\hline $36-1,64-67$ & 328.14 & 81 & 10 & - & - & - & 9 & & 22 & - & - & 10 & 20 \\
\hline $37-1,114-116$ & 338.14 & 52 & 19 & - & - & - & 29 & & 11 & - & - & 19 & 12 \\
\hline $37-4,35-37$ & 341.85 & 100 & - & - & - & - & - & & 1 & 3 & - & 2 & 8 \\
\hline $38-1,66-68$ & 347.16 & 77 & 11 & - & - & - & 12 & & 5 & - & - & 7 & 31 \\
\hline $38-4,66-68$ & 351.66 & 52 & 15 & - & - & - & 33 & & 4 & 7 & - & 6 & 8 \\
\hline $39-2,137-139$ & 358.87 & 100 & - & - & _ & - & - & & 2 & - & - & - & 6 \\
\hline $40-1,38-40$ & 365.88 & 100 & - & - & - & - & - & & - & - & - & - & 13 \\
\hline $40-2,46-48$ & 367.46 & 76 & - & - & - & - & 24 & & 5 & - & - & 4 & 6 \\
\hline $40-3,100-103$ & 369.50 & 100 & - & - & - & - & - & & - & - & - & trace & 7 \\
\hline $41-2,76-78$ & 377.26 & 100 & - & - & - & - & - & & 4 & 3 & - & - & - \\
\hline $41-3,59-62$ & 378.59 & 100 & - & - & - & - & - & & - & trace & - & - & - \\
\hline $42-1,116-118$ & 385.66 & 100 & - & - & - & - & - & & trace & 5 & - & - & - \\
\hline $42-3,14-16$ & 387.64 & 100 & - & - & - & - & - & & 1 & - & - & - & 3 \\
\hline $43-1,103-105$ & 395.03 & 70 & 30 & - & - & - & - & & 5 & - & - & 6 & 9 \\
\hline
\end{tabular}

carbonates, variable (10 to $70 \%$ ); and quartz and feldspars, present.

This assemblage is identical with Assemblage 3 at Sites 403 and 404 . The detrital nature of the sedimentation resumes (quartz, feldspars). The predominance of illite and the abundance of chlorite attest to the arrival of sediment of a northern type, to a cooling in the climate, and to the development of deep-ocean circulation in a north-south direction.

\section{SYNTHESIS AND CONCLUSIONS}

Three entirely contrasting mineralogical assemblages are found in succession along the line of holes sunk in the four sites. The oldest of these shows conflicting characteristics at Sites 403 and 404 (Assemblage 1) on the one hand, and at Sites 405 and 406 (Assemblage 1B) on the other (Figures 5 and 6).

The two more recent assemblages ( 2 and 3 ) are, however, virtually identical in all four sites.

Mineralogical Assemblage 1 is characteristic of detrital sedimentation, apparently inherited in the main from basic volcanic rocks. Conditions of weathering under a hot, damp climate with contrasting seasons may in addition have been instrumental in producing this type of assemblage. Sedimentation of this nature involves in particular the lower Eocene 
TABLE 2

X-Ray Diffraction Analysis of the Fine-Grained $(<2 \mu \mathrm{m})$ and Bulk Samples From Site 404

\begin{tabular}{|c|c|c|c|c|c|c|c|c|c|c|c|c|c|}
\hline \multirow[b]{3}{*}{$\begin{array}{c}\text { Sample } \\
\text { (Interval in } \mathrm{cm} \text { ) }\end{array}$} & \multirow[b]{3}{*}{$\begin{array}{l}\text { Depth } \\
\text { (m) }\end{array}$} & \multicolumn{7}{|c|}{$<2 \mu$ m Fraction } & \multicolumn{5}{|c|}{ Bulk Sediment } \\
\hline & & \multirow[b]{2}{*}{ 䔍 } & \multirow[b]{2}{*}{ 冚 } & \multirow[b]{2}{*}{ 苛 } & \multirow[b]{2}{*}{ 을 } & \multirow[b]{2}{*}{ 莺总 } & \multirow[b]{2}{*}{ 苞 } & \multirow[b]{2}{*}{ Comment } & \multirow[b]{2}{*}{ 총 } & \multirow[b]{2}{*}{ 总 } & \multirow[b]{2}{*}{ ัㅗㅇ } & \multicolumn{2}{|c|}{ Feldspar } \\
\hline & & & & & & & & & & & & 穿 & 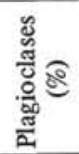 \\
\hline $1-1,70-72$ & 0.70 & 17 & 49 & 17 & 17 & - & - & & 14 & 32 & - & 1 & 2 \\
\hline $14,133-135$ & 5.83 & 21 & 46 & 25 & 8 & - & - & & 5 & 33 & - & 4 & 8 \\
\hline $2-1,47-49$ & 21.97 & 23 & 49 & 9 & 19 & - & - & & 10 & 35 & - & 4 & 8 \\
\hline $2-2,88-90$ & 23.88 & 44 & 29 & 11 & 16 & - & - & & 8 & 37 & - & - & 12 \\
\hline $2-4,76-78$ & 26.76 & 41 & 33 & 9 & 17 & - & - & & 4 & 50 & - & 2 & 1 \\
\hline $2-5,134-136$ & 28.84 & - & 62 & 18 & 20 & - & - & & 4 & 53 & - & 21 & trace \\
\hline $2-6,96-97$ & 29.96 & 44 & 30 & 12 & 14 & - & - & & 2 & 68 & - & - & - \\
\hline $2-6,127-129$ & 30.27 & 39 & 36 & 16 & 9 & - & - & & 4 & 48 & - & trace & 2 \\
\hline $3-1,73-75$ & 104.73 & 28 & 46 & 13 & 13 & - & - & & - & 90 & - & - & - \\
\hline $4-2,67-69$ & 172.67 & 65 & 21 & 9 & 5 & - & - & & trace & 90 & - & - & - \\
\hline $5-1,84-86$ & 180.84 & 58 & 9 & 9 & trace & - & 9 & & - & 86 & - & - & - \\
\hline $5-2,141-143$ & 182.91 & 100 & - & - & - & - & - & & - & 78 & - & - & - \\
\hline $7-2,25-28$ & 200.75 & 100 & - & - & - & - & - & not much clay & - & 12 & - & trace & trace \\
\hline $8-1,98-102$ & 209.48 & 100 & - & - & - & - & - & & - & 7 & - & 6 & 6 \\
\hline $11-1,57-66$ & 237.57 & 32 & - & - & - & - & 68 & & - & 5 & - & - & - \\
\hline $11-1,40-42$ & 265.90 & 100 & - & - & - & - & - & not much clay & - & - & - & trace & 5 \\
\hline $16-1,127-129$ & 285.77 & 8 & - & - & - & - & 92 & not much clay & 6 & 10 & - & - & 8 \\
\hline $17-3,52-54$ & 297.52 & 40 & - & - & - & - & 60 & not much clay & 6 & - & - & - & 7 \\
\hline $17-6,12-14$ & 301.62 & 75 & trace & - & - & - & 25 & & trace & 5 & - & 2 & 17 \\
\hline $18-2,15-18$ & 305.15 & 100 & - & - & - & - & trace & not much clay & 4 & 3 & - & trace & 12 \\
\hline $21-1,7-9$ & 332.07 & 100 & - & - & - & - & - & not much clay & 2 & 30 & - & 1 & 3 \\
\hline $22-1,8-10$ & 341.58 & 44 & - & - & - & - & 56 & not much clay & 17 & - & - & 8 & 34 \\
\hline $22-3,131-133$ & 345.81 & 60 & 20 & - & - & - & 20 & & trace & 3 & - & 1 & 13 \\
\hline $22-4,131-133$ & 347.31 & 28 & - & - & - & - & 72 & & 4 & - & - & 17 & 17 \\
\hline $23-1,115-117$ & 352.15 & 47 & 18 & - & - & - & 35 & & 6 & 33 & - & 2 & 14 \\
\hline $23-5,147-150$ & 358.47 & 100 & trace & - & - & - & trace & & 5 & - & - & 5 & 22 \\
\hline $25-1,5-7$ & 370.05 & 100 & trace & - & - & - & - & not much clay & 2 & 17 & - & 16 & - \\
\hline $26-1,14-16$ & 379.64 & 100 & trace & - & - & - & - & not much clay & trace & - & - & trace & trace \\
\hline
\end{tabular}

(Site 403 ) but continues up to and including the middle Miocene at Site 404.

Mineralogical Assemblage 1B (Sites 405 and 406) reveals sedimentation of chemical or biochemical nature, rich in silica and whose origin could be either climatic or hydrothermal. This type of sedimentation develops in the Eocene and continues to the end of the lower Miocene (Site 406).

Mineralogical Assemblage 2 (Sites 403, 404, 405 and 406) reflects a pelagic sedimentation, with deposits rich in carbonated biogenic elements. Detrital components, exclusively clay, are scarce. Among them, smectites in large proportions reflect continued alimentation in fine-grained matter, originating in soils formed under a hot climate with contrasting seasons. But the sudden appearance of illites and chlorites indicates an additional influx of other types of supply, formed under colder climates and probably transported by deep-water currents. This acts as a marker for the different stages in the establishment of deep-water circulation in the various areas of drilling. The effects of this circulation are brusquely apparent at the middle Eocene at Site 403 , between the lower and middle Miocene at Site 406, and between the middle and upper Miocene at Site 404. As for Site 405, this type of sedimentation occurs only very briefly during the upper Miocene. The upper limit of this assemblage is, however, practically contemporaneous in all four sites and can be placed in the Pliocene; the break is seen very clearly at Site 406 during the lower Pliocene.

Mineralogical Assemblage 3 (Sites 403, 404, 405 and 406) reflects a resumption of erosion (quartz and feldspars) and a cooling of the climate (illites predominant, chlorites abundant) in the late Pliocene and the Pleistocene.

The similarity in sedimentation in Assemblages 2 and 3, following the sharply contrasted Assemblages 1 and 1B, shows that an appreciable change in ocean circulation occurred after the middle Eocene (Site 403) or the lower, middle, or upper Miocene (Sites 406, 404, and 405, respectively). The divergence in the timing of this transformation results partly from gaps in sedimentation. It may also be connected with local differences in tectonic phenomena and subsequent readjustments. As a result of the change, the pattern of sedimentation (previously dependent on local peculiarities, including basins of detrital sedimentation and chemical sedimentation) assumes a uniform, pelagic character over the entire zone under study. Subsequently, sedimentation is of the modern North Atlantic type, and denotes both a marked cooling in the climate and the development of deep-sea currents from the north.

\section{ACKNOWLEDGMENTS}

We wish to thank R. W. Thompson, L. Montadert, D. G. Roberts who made it possible for us to participate in this study.

We acknowledge the contribution of the scientific officers involved. We are also very grateful to Pr. G. Millot for critically reviewing the manuscript and for making valuable suggestions for improvement.

This investigation was supported in part by ATP No. 2685 from the Centre National de la Recherche Scientifique. 


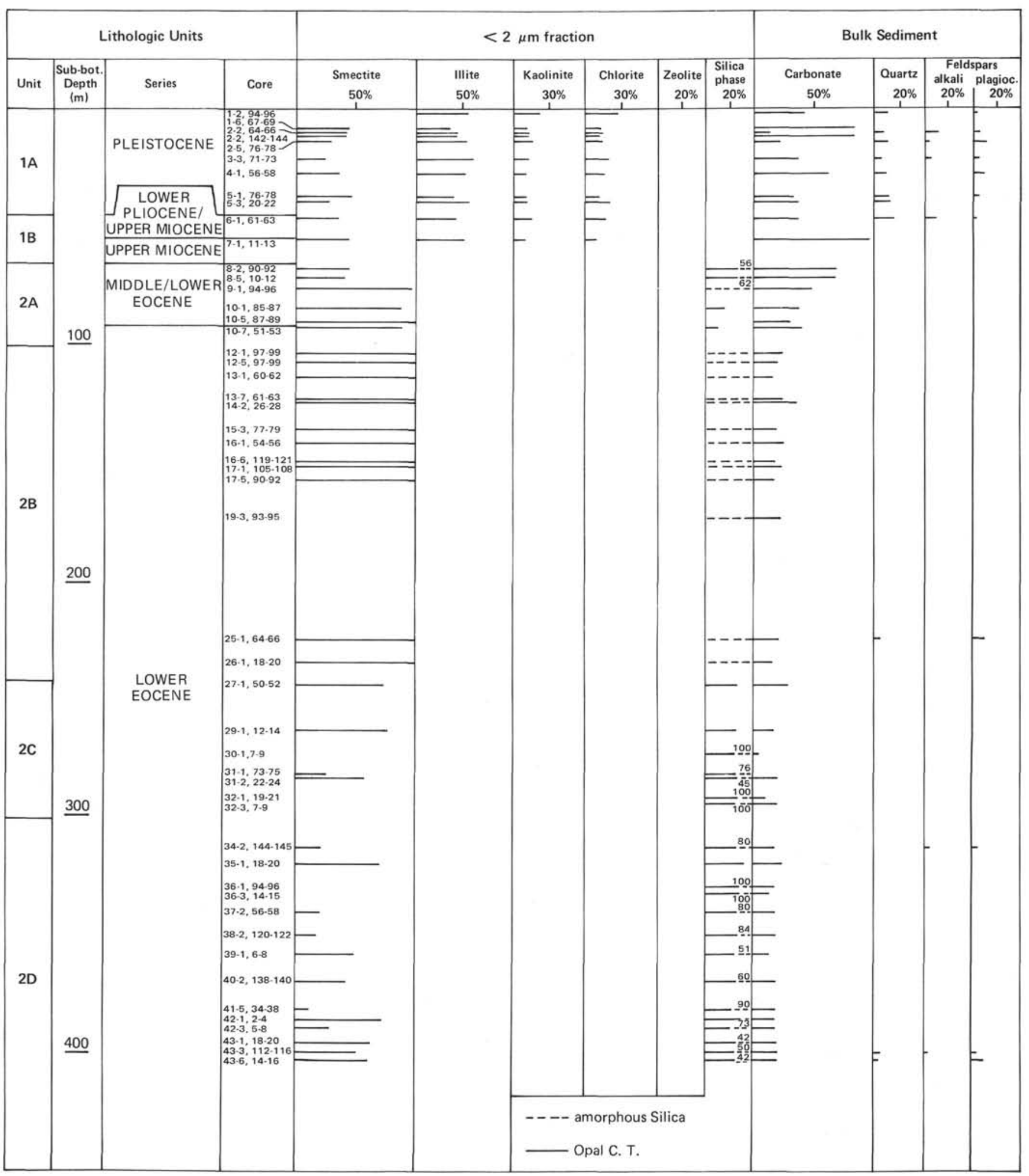

Figure 3. Mineralogical log of Site 405 .

\section{REFERENCES}

Biscaye, P. E., 1965. Mineralogy and sedimentation of Recent deep sea clay in the Atlantic Ocean and adjacent seas and oceans, Geol. Soc. Am. Bull., v. 76, p. 803-832.

Bonatti, E., 1967. Mechanisms of deep sea volcanism in the South Pacific, Researches in Geochemistry, v. 2, p. 453-491.
Brown, G., 1961. The X-ray identification and crystal structures of clay minerals: London (Mineralogical society), p. 544.

Chamley, H., 1971. Recherches sur la sédimentation argileuse en Mediteranée, Sci Géol. Mem., Strasbourg, no. 35, p. 209.

Fan Pow-Foong, F. and Zemmels, I., 1972. X-ray mineralogy studies-Leg 12. In Berggren, W. A., Laughton, A. S., et al., 


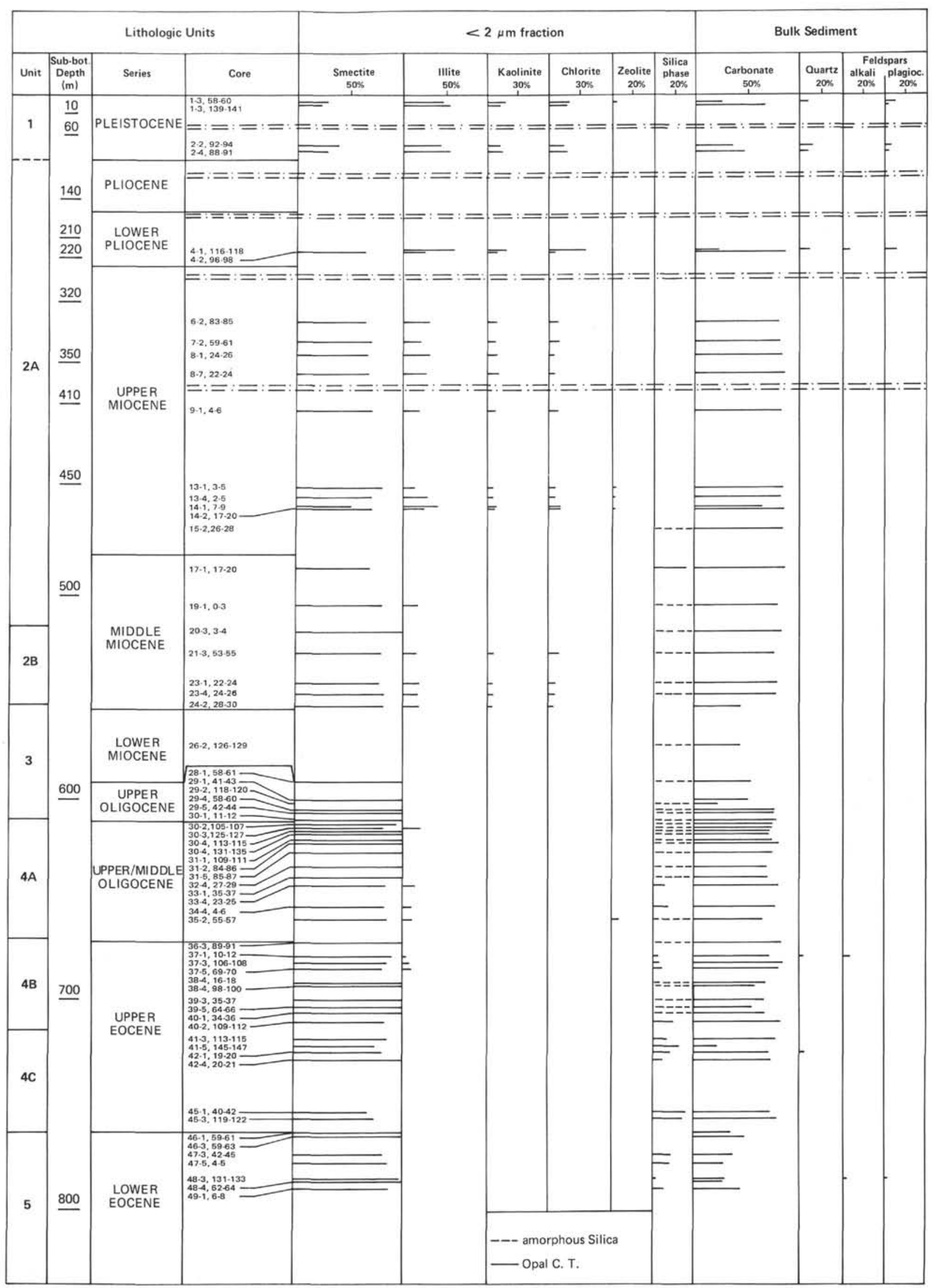

Figure 4. Mineralogical log of Site 406. 
TABLE 3

X-Ray Diffraction Analysis of the Fine-Grained $(<2 \mu \mathrm{m})$ and Bulk Samples From Site 405

\begin{tabular}{|c|c|c|c|c|c|c|c|c|c|c|c|c|}
\hline \multirow[b]{3}{*}{$\begin{array}{c}\text { Sample } \\
\text { (Interval in } \mathrm{cm} \text { ) }\end{array}$} & \multirow[b]{3}{*}{$\begin{array}{l}\text { Depth } \\
\text { (m) }\end{array}$} & \multicolumn{6}{|c|}{$<2 \mu$ m Fraction } & \multicolumn{5}{|c|}{ Bulk Sediment } \\
\hline & & \multirow[b]{2}{*}{ 苞 } & \multirow[b]{2}{*}{ 当疋 } & \multirow[b]{2}{*}{ 营 } & \multirow[b]{2}{*}{ 영 } & \multirow[b]{2}{*}{ 总总 } & \multirow[b]{2}{*}{ 苞 } & \multirow[b]{2}{*}{ ปี } & \multirow[b]{2}{*}{ 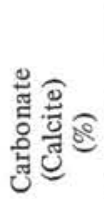 } & \multirow[b]{2}{*}{ 응 } & \multicolumn{2}{|c|}{ Feldspar } \\
\hline & & & & & & & & & & & 丞 & 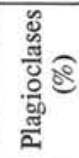 \\
\hline $1-2,94-96$ & 2.44 & trace & 54 & 19 & 27 & - & trace & 13 & 40 & - & trace & 1 \\
\hline $1-6,67-69$ & 8.17 & 44 & 29 & 11 & 14 & - & - & trace & 82 & - & - & - \\
\hline $2-2,64-66$ & 10.14 & 42 & 32 & 13 & 13 & - & - & 7 & 13 & - & 11 & 5 \\
\hline $2-2,142-144$ & 10.92 & 42 & 34 & 14 & 10 & - & - & trace & 83 & - & - & - \\
\hline $2-5,76-78$ & 14.76 & 29 & 42 & 15 & 14 & - & - & 12 & 20 & - & 2 & 11 \\
\hline $3-3,71-73$ & 21.21 & 23 & 47 & 11 & 19 & - & - & 7 & 35 & - & 4 & 4 \\
\hline $4-1,56-58$ & 27.56 & 35 & 40 & 9 & 16 & - & - & 7 & 61 & - & - & 8 \\
\hline $5-1,76-78$ & 37.26 & 46 & 31 & 12 & 11 & - & - & 9 & 31 & - & - & 6 \\
\hline $5-3,20-f 2$ & 39.70 & 27 & 43 & 11 & 19 & - & - & 12 & 36 & - & - & - \\
\hline $6-1,61-63$ & 46.61 & 36 & 15 & 17 & - & - & - & 15 & 37 & - & 12 & 14 \\
\hline $7-1,11-13$ & 55.61 & 43 & 37 & 10 & 10 & - & - & - & 96 & - & - & - \\
\hline $8-2,90-92$ & 67.40 & 44 & - & - & - & - & 56 & - & 69 & - & - & - \\
\hline $8-5,10-12$ & 71.10 & 38 & - & - & - & - & 62 & - & 68 & - & - & - \\
\hline $9-1,94-96$ & 75.44 & 100 & - & - & - & - & - & - & 48 & - & - & - \\
\hline $10-1,85-87$ & 84.85 & 86 & - & - & - & - & 14 & - & 36 & - & trace & - \\
\hline $10-5,85-89$ & 90.87 & 100 & - & - & - & - & presence & - & 29 & - & - & - \\
\hline $10-7,51-53$ & 93.51 & 90 & - & - & - & - & 10 & trace & 40 & - & - & - \\
\hline $12-1,97-99$ & 103.93 & 100 & - & - & - & - & - & - & 25 & - & - & - \\
\hline $12-5,97-99$ & 109.93 & 100 & - & - & - & - & - & - & 20 & - & - & - \\
\hline $13-1,60-62$ & 113.10 & 100 & - & - & - & - & - & - & 17 & - & trace & trace \\
\hline $13-7,61-63$ & 122.11 & 100 & - & - & - & - & - & - & 22 & - & - & - \\
\hline $14-2,26-28$ & 123.76 & 100 & - & - & - & - & - & - & 36 & - & - & - \\
\hline $15-3,77-79$ & 135.27 & 100 & - & - & - & - & - & - & 17 & - & - & - \\
\hline $16-1,54-56$ & 141.54 & 100 & - & - & - & - & - & - & 25 & - & - & - \\
\hline $16-6,119-121$ & 149.69 & 100 & - & - & - & - & - & - & 15 & - & trace & trace \\
\hline $12-1,105-108$ & 151.55 & 100 & - & - & - & - & - & - & 22 & - & - & - \\
\hline $17-5,90-92$ & 157.40 & 100 & - & - & - & - & - & trace & 18 & - & trace & - \\
\hline $19-3,93-95$ & 173.43 & - & - & - & - & - & - & - & 22 & - & - & - \\
\hline $25-1,64-66$ & 227.14 & 100 & - & - & - & - & - & - & 23 & - & - & 8 \\
\hline $26-1,18-20$ & 236.18 & 100 & - & - & - & - & - & - & 17 & - & _ & - \\
\hline $27-1,50-52$ & 246.00 & 73 & - & - & - & 27 & - & - & 28 & - & - & - \\
\hline $29-1,12-14$ & 264.62 & 76 & - & - & - & 24 & - & - & 18 & - & - & - \\
\hline $30-1,7-9$ & 274.07 & - & - & - & - & 100 & - & - & 3 & - & - & - \\
\hline $31-1,73-75$ & 284.23 & 24 & - & - & - & 76 & - & - & - & - & - & - \\
\hline $31-2,22-24$ & 285.22 & 55 & - & - & - & 45 & - & - & 20 & - & - & - \\
\hline $32-1,19-21$ & 293.19 & - & - & - & - & 100 & - & - & 10 & - & - & - \\
\hline $32-3,7-9$ & 296.07 & trace & - & - & - & 100 & - & - & 20 & _ & - & - \\
\hline $34-2,144-145$ & 314.94 & 20 & - & - & - & 80 & - & trace & 15 & - & 2 & 3 \\
\hline $35-1,18-20$ & 321.64 & 68 & - & - & - & 32 & - & - & 22 & - & - & - \\
\hline $36-1,94-96$ & 331.94 & - & - & - & - & 100 & - & - & 15 & - & - & - \\
\hline $36-3,14-15$ & 334.14 & - & - & - & - & 100 & - & - & 12 & - & - & - \\
\hline $37-2,56-58$ & 342.56 & 20 & - & - & - & 80 & - & - & 16 & _ & - & - \\
\hline $38-2,120-122$ & 352.70 & 16 & - & - & - & 84 & - & - & 17 & - & - & - \\
\hline $39-1,6-8$ & 359.56 & 49 & - & - & - & 51 & - & - & 12 & - & - & - \\
\hline $40-2,138-140$ & 371.88 & 40 & - & - & - & 60 & - & - & 17 & - & - & - \\
\hline $41-5,34-36$ & 384.84 & 10 & - & - & - & 90 & - & trace & 17 & - & 2 & 2 \\
\hline $42-1,2-4$ & 388.02 & 71 & - & - & - & 29 & - & trace & 17 & - & - & - \\
\hline $42-3,5-8$ & 391.05 & 27 & - & - & - & 73 & - & - & 17 & - & - & _ \\
\hline $43-1,18-20$ & 397.68 & 58 & - & - & - & 42 & - & - & 20 & - & trace & trace \\
\hline $43-3,112-114$ & 401.62 & 50 & - & - & - & 50 & - & 1 & 21 & - & 2 & 1 \\
\hline $43-6,14-16$ & 405.14 & 58 & - & - & - & 42 & - & 1 & 17 & - & - & 5 \\
\hline
\end{tabular}

Initial Reports of the Deep Sea Drilling Project, v. 12: Washington (U.S. Government Printing Office), p. 1127-1154. Goldberg, E. C., 1959. Physics and chemistry of the earth, p. 294. Greenwood, R., 1973. Cristobalite: its relationship to chert formation in selected samples from the Deep Sea Drilling Project, $J$. Sed. Petrol., v. 43, p. 700-708.

Griffin, J. J., Window, H., and Goldberg, E. D., 1968. The distribution of clay minerals in the world ocean, Deep-sea Research, v. 15, p. 433-459.
Griffin, J. J., Koide, M., Hohndorf, A., Hawkins, J. W., and Goldberg, E. D., 1972. Sediments of the Law Basin-rapidly accumulating volcanic deposits, Deep-sea Research, v. 19, p. $139-148$.

Jones, J. B. and Segnit, E.R., 1971. The nature of opal. 1 nomenclature and costituent phases, J. Geol. Soc. Aust., v. 18, p. 57-68.

Latouche, C., 1971. Les argiles des bassins alluvionnaires aquitains et des dépendances océaniques. Contribution à l'étude d'un environnement. Thèse Sci. Nat., Bordeaux, p. 415. 
TABLE 4

X-Ray Diffraction Analysis of the Fine-Grained $(<2 \mu \mathrm{m})$ and Bulk Samples From Site 406

\begin{tabular}{|c|c|c|c|c|c|c|c|c|c|c|c|c|}
\hline \multirow[b]{3}{*}{$\begin{array}{c}\text { Sample } \\
\text { (Interval in } \mathrm{cm} \text { ) }\end{array}$} & \multirow[b]{3}{*}{$\begin{array}{l}\text { Depth } \\
\text { (m) }\end{array}$} & \multicolumn{6}{|c|}{$<2 \mu$ m Fraction } & \multicolumn{5}{|c|}{ Bulk Sediment } \\
\hline & & \multirow[b]{2}{*}{ 芯 } & \multirow[b]{2}{*}{ 总气 } & \multirow[b]{2}{*}{ 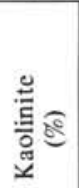 } & \multirow[b]{2}{*}{$\frac{2}{\tilde{c}}$} & & & & & & Felc & spar \\
\hline & & & & & & 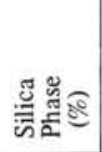 & 홍 & 苟 & 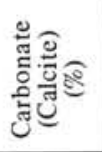 & 气ั & 莺 & 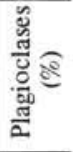 \\
\hline $1-3,58-60$ & 3.58 & 28 & 38 & 16 & 18 & - & trace & 7 & 25 & - & - & 11 \\
\hline $1-3,139-141$ & 4.39 & 21 & 45 & 15 & 19 & - & - & 1 & 66 & - & - & 2 \\
\hline $2-2,92-94$ & 64.42 & 39 & 35 & 13 & 13 & - & - & 11 & 33 & - & - & 6 \\
\hline $2-4,88-91$ & 67.38 & 28 & 41 & 15 & 16 & - & - & 5 & 45 & - & - & 3 \\
\hline $3-1,92-94$ & 138.92 & 82 & - & - & - & 18 & - & - & 91 & - & - & - \\
\hline $4-1,116-118$ & 215.16 & - & 48 & 18 & 34 & - & - & 9 & 22 & - & 6 & 12 \\
\hline $4-2,96-98$ & 216.46 & 64 & 21 & 9 & 6 & - & - & - & 89 & - & - & - \\
\hline $6-2,83-85$ & 330.33 & 62 & 24 & 7 & 7 & - & - & trace & 82 & - & - & - \\
\hline $7-2,59-61$ & 339.59 & 68 & 18 & 7 & 7 & - & - & trace & 82 & - & - & - \\
\hline $8-1,24-26$ & 347.24 & 66 & 24 & 7 & 3 & - & - & trace & 84 & - & - & - \\
\hline $8-7,22-24$ & 356.22 & 65 & 20 & 11 & 4 & - & - & 1 & 86 & - & - & - \\
\hline $9-1,4-6$ & 413.54 & 72 & 16 & 6 & 6 & - & - & - & 82 & - & - & - \\
\hline $13-1,3-5$ & 451.53 & 80 & 10 & 5 & 5 & - & trace & trace & 84 & - & - & - \\
\hline $13-4,2-5$ & 456.02 & 68 & 21 & 5 & 6 & - & presence & trace & 82 & - & - & - \\
\hline $14-1,7-9$ & 461.07 & 50 & 33 & 8 & 9 & - & - & trace & 66 & - & - & - \\
\hline $14-2,17-20$ & 462.67 & 68 & 20 & 6 & 6 & - & trace & - & 85 & - & - & - \\
\hline $15-2,26-28$ & 472.26 & 69 & 18 & 9 & 4 & - & - & trace & 85 & - & - & - \\
\hline $17-1,17-20$ & 489.67 & 69 & - & - & - & 31 & - & trace & 87 & - & - & 2 \\
\hline $19-1,0-3$ & 508.50 & 81 & 19 & - & - & - & - & - & 79 & - & - & - \\
\hline $20-3,3-4$ & 521.03 & 100 & - & - & - & - & - & - & 82 & - & - & - \\
\hline $21-3,53-55$ & 531.03 & 78 & 11 & 4 & 7 & - & - & trace & 77 & - & - & - \\
\hline $23-1,22-24$ & 546.72 & 77 & 14 & 4 & 5 & - & - & trace & 77 & - & - & - \\
\hline $23-4,24-26$ & 551.24 & 81 & 13 & 3 & 3 & - & - & trace & 76 & - & - & - \\
\hline $24-2,28-30$ & 557.78 & 81 & 12 & 5 & 2 & - & - & 2 & $44^{\circ}$ & - & - & - \\
\hline $26-2,126-129$ & 577.76 & - & - & - & - & - & - & - & 44 & - & - & - \\
\hline $28-1,58-61$ & 594.58 & 100 & - & - & - & - & - & - & 51 & - & - & - \\
\hline $29-1,41-43$ & 603.91 & 100 & trace & trace & trace & - & - & 1 & 50 & - & - & - \\
\hline $29-2,118-120$ & 606.18 & - & - & - & - & - & - & - & 20 & - & - & - \\
\hline $29-4,58-60$ & 608.58 & 100 & trace & trace & trace & - & - & - & 74 & - & - & - \\
\hline $29-5,42-44$ & 609.92 & 100 & trace & trace & trace & - & - & trace & 74 & - & - & - \\
\hline $30-1,11-12$ & 613.11 & 100 & - & - & - & trace & - & - & 79 & - & - & - \\
\hline $30-2,105-107$ & $6: 5.55$ & 100 & - & - & - & - & - & trace & 77 & - & - & - \\
\hline $30-3,125-127$ & 617.25 & 83 & 17 & - & - & - & - & trace & 74 & - & - & - \\
\hline $30-4,113-115$ & 618.63 & 100 & trace & - & - & - & - & trace & 74 & - & - & - \\
\hline $30-4,131-133$ & 618.81 & 100 & trace & - & - & - & - & trace & 71 & - & - & $\therefore$ \\
\hline $31-1,109-111$ & 623.59 & 100 & trace & - & - & - & - & - & 74 & - & - & - \\
\hline $31-2,84-86$ & 624.84 & 100 & trace & - & - & - & - & - & 79 & - & - & - \\
\hline $31-5,85-87$ & 629.35 & 100 & trace & - & - & - & - & trace & 76 & - & - & - \\
\hline $32-4,27-29$ & 636.77 & 100 & - & - & - & trace & - & trace & 69 & - & - & - \\
\hline $33-1,35-37$ & 641.85 & 100 & trace & - & - & - & - & - & 68 & - & - & - \\
\hline $33-4,23-25$ & 646.23 & 82 & 10 & - & - & 8 & - & trace & 79 & - & - & - \\
\hline $34-4,4-6$ & 655.54 & 81 & 6 & - & - & 13 & - & trace & 78 & - & - & - \\
\hline $35-2,55-57$ & 662.55 & 84 & 10 & - & - & - & 6 & trace & 66 & - & - & - \\
\hline $36-3,89-91$ & 673.89 & 100 & trace & - & - & - & presence & - & 84 & - & - & - \\
\hline $37-1,10-12$ & 679.60 & 91 & 4 & - & - & 5 & - & 1 & 71 & - & 5 & - \\
\hline $37-3,106-108$ & 683.56 & 86 & 6 & - & - & - & 8 & - & 86 & - & - & - \\
\hline $37-5,69-70$ & 686.19 & 82 & 7 & - & - & 11 & - & trace & 81 & - & - & - \\
\hline $38-4,16-18$ & 693.66 & 100 & - & - & - & - & - & - & 68 & - & - & - \\
\hline $38-4,98-100$ & 694.48 & 100 & - & - & - & - & - & trace & 59 & - & - & - \\
\hline $39-3,35-37$ & 701.85 & 100 & - & - & - & - & - & - & 68 & - & - & - \\
\hline $39-5,64-66$ & 705.14 & 100 & - & - & - & - & - & trace & 54 & - & - & - \\
\hline $40-1,34-36$ & 708.34 & 100 & - & - & - & - & - & trace & 68 & - & - & - \\
\hline $40-3,109-112$ & 712.09 & 81 & - & - & - & 19 & - & trace & 81 & - & - & - \\
\hline $41-3,113-115$ & 721.63 & 86 & trace & - & - & 14 & - & - & 76 & - & - & - \\
\hline $41-5,145-147$ & 724.95 & 74 & - & - & - & 26 & - & - & 20 & - & - & - \\
\hline $42-1,19-20$ & 727.19 & 82 & - & - & - & 18 & - & 1 & 71 & - & - & - \\
\hline $42-4,20-21$ & 731.70 & 95 & - & - & - & 5 & - & trace & 71 & - & - & - \\
\hline $45-1,40-42$ & 755.90 & 67 & - & - & - & 33 & - & - & 74 & - & - & - \\
\hline $45-3,119-122$ & 759.69 & 71 & - & - & - & 29 & - & trace & 79 & - & - & - \\
\hline $46-1,59-61$ & 765.59 & 100 & - & - & - & trace & presence & - & 33 & - & - & - \\
\hline $46-3,59-63$ & 768.59 & 100 & - & - & - & trace & - & - & 46 & - & - & - \\
\hline $47-3,42-45$ & 777.92 & 82 & - & - & - & 18 & - & - & 35 & - & - & - \\
\hline $47-5,4-5$ & 780.54 & 85 & - & - & - & 15 & - & - & 26 & - & - & - \\
\hline $48-3,131-133$ & 788.31 & 97 & - & - & - & 3 & - & trace & 28 & - & - & - \\
\hline $48-4,62-64$ & 789.12 & 100 & - & - & - & trace & - & trace & 23 & - & trace & trace \\
\hline $49-1,6-8$ & 793.56 & 90 & - & - & - & 10 & - & trace & 43 & - & trace & - \\
\hline
\end{tabular}




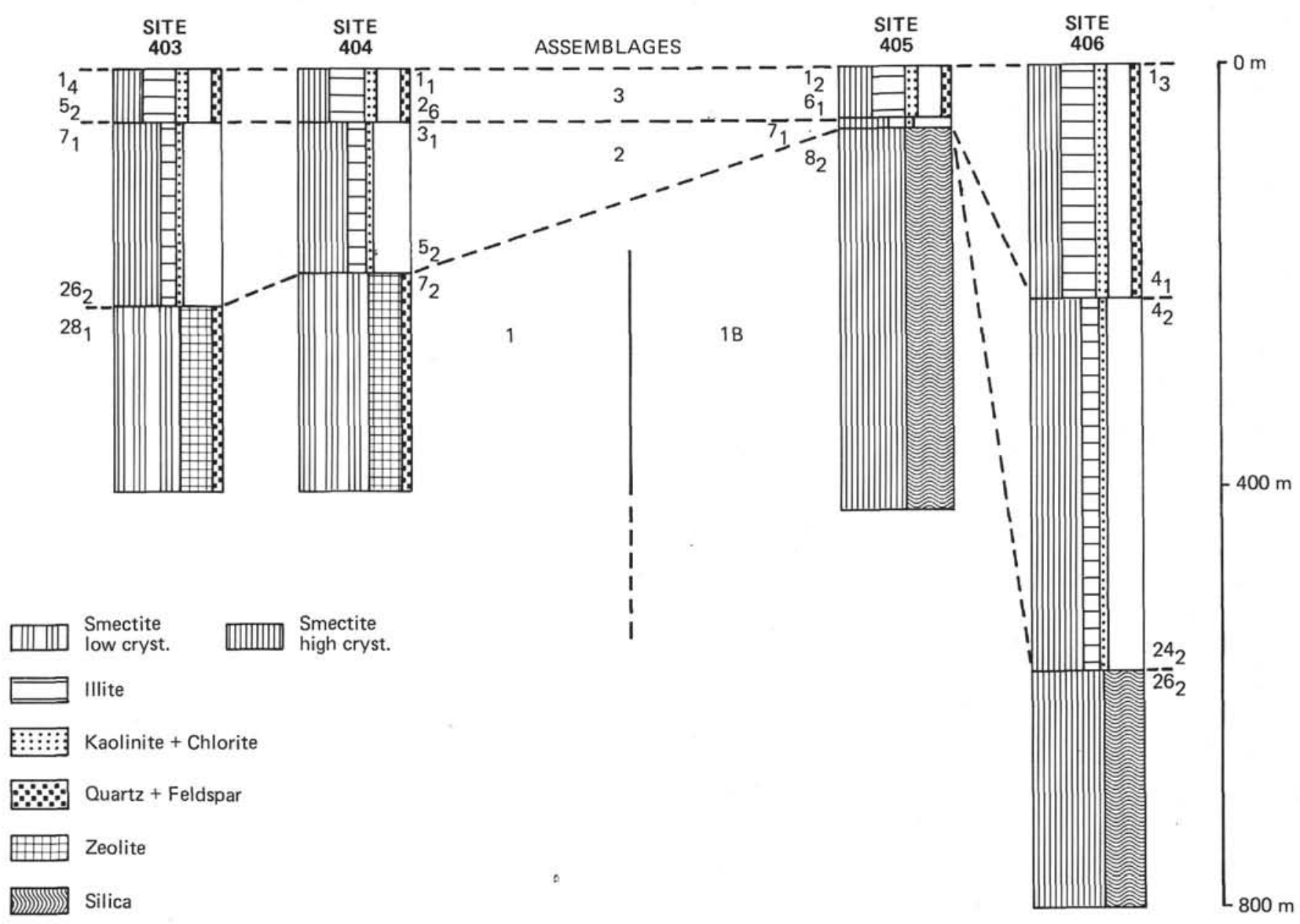

Figure 5. Mean values and relative thickness of the mineralogical assemblages.

1975. Les minéraux argileux des sédiments actuels de l'Atlantique Nord-oriental et du Sud de la Mer de Norvège, Proceedings Intern. Clay Conf., Mexico, 16-23 July, p. 45-54.

Leclaire, L., 1974. Hypothèse sur l'origine des silicifications dans les grands bassins océaniques. Le rôle des climats hydrolsants, Bull. Soc. Géol. France, v. 7, p. 214-224.

Mason, B. and Sand, L.B., 1960. Clinoptilolite from Patagonia. The relationship between clinoptilolite and heulondite, $\mathrm{Am}$. Mineral., v. 45 , p. $341 \cdot 350$.

Millot, G., 1964. Géologie des argiles: Paris (Masson et Cie), p. 499.

Mumpton, F. A., 1960. Clinoptilolite redefined, Am. Mineral, v. 45, p. $351-369$.

Nayudu, Y. R., 1964. Palagonite tuffs (hyaloclastites) and the products of post-eruptive processes, Bull. Volcanol., v. 27, p. $391-410$.
Paquet, H., 1969. Evolution géochimique des minéraux argileux dans les altérations et les sols des climats méditerranéens et tropicaux à saisons contrastées, Mém. Serv. Carte Géol., Alsace-Lorraine no. 30, p. 212.

Rateev, M. A., Gorbunova, Z. N., Lisitzyn, A. P., and Nosov, G. L., 1969. The distribution of clay minerals in the oceans, Sedimentology, v. 13, p. 21-43.

Tardy, Y., 1969. Géochimie des altérations. Etude des arènes et des eaux de quelques massifs cristallins d'Europe et d'Afrique, Mém. Serv. Carte Géol. Alsace-Lorraine, no. 31, p. 199.

Thorez, J., 1975. Phyllosilicates and clay minerals: Dison, (Lelotte Ed.), p. 582.

Trichet, J., 1970. Contribution à l'étude de l'alteration expérimentale des verres volcaniques. Travaux de Laboratoire de Géologie de l'Ecole Normale Supérieure, Paris, p. 152.

Yeroschev-Shak, V. A., 1954. Clay minerals of the Atlantic Ocean. Soviet, Oceanography, 30-2, p. 90-106. 
C. LATOUCHE, N. MAILLET

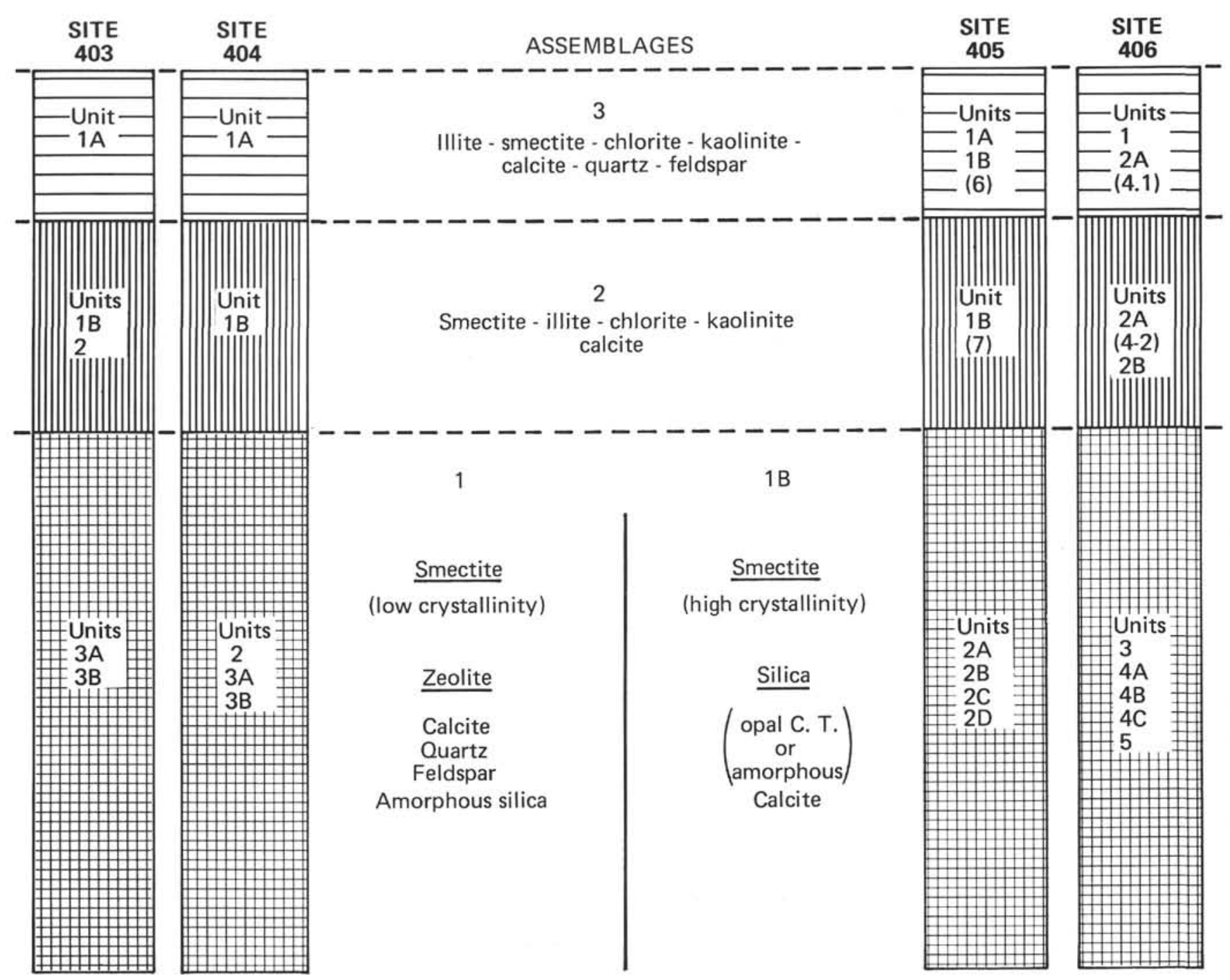

Figure 6. Schematic diagram of the mineralogical assemblages of the lithological units. 